\title{
Téoros
}

Revue de recherche en tourisme

\section{Charting Adventure Tourism Development in the North}

\section{Labrador's Wilderness Experience}

\section{John S. Hull}

Volume 18, numéro 2, été 1999

La nordicité

URI : https://id.erudit.org/iderudit/1072060ar

DOI : https://doi.org/10.7202/1072060ar

Aller au sommaire du numéro

Éditeur(s)

Université du Québec à Montréal

ISSN

0712-8657 (imprimé)

1923-2705 (numérique)

Découvrir la revue

Citer cet article

Hull, J. S. (1999). Charting Adventure Tourism Development in the North:

Labrador's Wilderness Experience. Téoros, 18(2), 15-23.

https://doi.org/10.7202/1072060ar d'utilisation que vous pouvez consulter en ligne.

https://apropos.erudit.org/fr/usagers/politique-dutilisation/ 


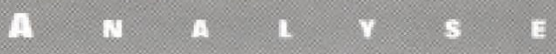

\section{Charting Adventure Tourism DeVelopment in the North}

\section{LABRADOR'S WILDERNESS EXPERIENCE}

\section{John S. Hull}

"Here is a country that one can visit at least expense with little danger and enjoy the freedom of primitive man. There are no big crowds, now hustling business centres, no millionaires or trusts, no smoke, no police, no magazines, no telegraphs or televisions. Here you can wander at will. go where you like, do as you please. No one owns any land. All here is a country suggesting the bondage of an ice age and a people sill smongly bearing the flavour of prehistoric times".".

Prowse, 1905, Labrador, The Newfoundland Guidebook

Labrador has a rich natural and cultural history that has captured the imagination of travelers for centuries. Explorers, Moravian missionaries, fishing and trapping merchants, wilderness adventurer's, and naturalists have been lured to Labrador and have left a legacy of journals, sketches, images, and maps of this Arctic region (Grey, 1858; Wallace, 1907; Grenfell, 1909; Boilieu, 1969; Lysaght, 1971). These documents have helped to foster a tremendous appeal for Labrador, its fragile northern wilderness and unique cultures that are attracting a growing number of visitors (Government of New foundland and Labrador, 1995). From Red Bay, the Basque Whaling capital of North America in the 16 th century in the south, to the rugged Torngat Mountains at the northern tip of the province, visitors at the end of the 20 th century are coming to explore centuries old fishing communities as well as unspoiled tundra, virgin forests, lakes and streams considered as one of the last frontiers on earth (Powell, 1979). The wealth of natural and cultural resources in the province has been recognized as having international market appeal and as one of Canada's leading adventure tourism re- sources (Economic Planning Group of Canada, 1996; Ethos Consulting, 1990). Tourist circuits such as "iceberg alley" and the "frontier circuit" are providing attractive options for visitors interested in this pristine environment (Government of Newfoundland and Labrador, 1999).

The purpose of this article is to document the touristic experience for visitors to $\mathrm{La}$ brador. This will be accomplished by an analysis of the historical changes in the regional tourist system through the application of Leiper's (1979) model. The model comprises three main elements-the tourist destination region, the transit routes, and the tourist generating regions. A review of Labrador as a destination will be followed by an analysis of the important transit routes that have served as the connecting threads which have brought visitors from the generating regions. This model was chosen in order to address not only the supply and demand issues of destination development in Labrador, but also to document the changes in the transportation penetration processes (Lundgren, 1995 ) that are making Labrador increasingly accessible for the visitor. Gunn
(1994: 78), in a visit to the province, pointed out that in developing a tourist region, it is necessary to consider "access from market origins, circulation corridors and destination zones with communities as focal points."

For many polar destinations in the Arctic, accessibility is an important consideration. Hall and Johnston (1995: 4) state that "access though difficult is available by air, land and sea." For Newfoundland and Labrador, access and transportation services are identified as serious constraints and a major challenge to development (Economic Planning Group of Canada, 1996).

\section{DESTINATION ATTRACTIONS-NATURAL}

Labrador is the peninsula of North America bounded by the Gulf of St. Lawrence, the North Atlantic, Hudson Strait, Hudson Bay, and in the southwest by Rupert River, Mistassini River, and Betsiamites River (see Fig. 1) (Grenfell, 1895). This vast, remote landmass, approximately 420,000 square miles, is located within the Arctic and Subarctic biomes of North America (Grenfell, 1895). Both biome regions are characterized by a cold, harsh climate with low temperatures and low precipitations that result in long winters and brief, cool summers in the north with short, warm summers in the south (Bone, 1992). Along the Labrador Coast, the arctic climate extends southward to the northern tip of Newfoundland due to the effects of the cold Labrador current. This current, in early summer, has become famous for the icebergs that it transports from Greenland to 
the coasts of Newfoundland and Labrador. In winter, due to cold temperatures, Labrador is also bounded by an impenetrable ice barrier (Boilieu, 1969). As a result, slow growth of biological life, natural vegetation, and soil formation have resulted in an extremely sensitive physical environment (Hall and Johnston, 1995; Bone, 1992). Lundgren (1995: 46) points out that the extreme seasonal temperatures in the Canadian North are factors that limit the prime winter and summer tourist seasons. Labrador is no exception.

Labrador also is located within a northern auroral zone or a broken ring of light that surrounds the North Pole. The zone is 4,000 kilometers in diameter and is " $[$... ] powered by particles from the sun, shaped by the earth's magnetic field and colored by gases in the upper atmosphere." (Savage, 1994: 14)

The auroral zone supports the mysterious, multicolored and fast-moving aurora borealis or northern lights that have become an important attraction for visitors to the North (Savage, 1994).

Geomorphically, Labrador is a part of the Canadian Shield, consisting of Precambrian rocks. In the north, the Canadian Shield is exposed at earth's surface and has been uplifted and glaciated, resulting in the creation of a dramatic, fjorded coastline that has received interim provincial protection as part of the Torngat Mountains National Park (WWF, 1998; Bone, 1992). Along the south shore there are outcroppings of Silurian sandstones, red syenite, and basalt while in the north an iridescent feldspar, labradorite, as well as copper pyrites, mica, and asbestos are found (Grenfell, 1895). These minerals are important historically, not only for their use as hunting tools, but also in the production of local crafts such as jewelry (Tuck, 1976).

The cold climate has created continuous, discontinuous, and sporadic permafrost zones from north to south that have influenced the presence and types of vegetation. Arctic vegetation can be divided into two zones-High Arctic and Low Arctic. In the High Arctic Zone, tundra vegetation is limited with lichens predominating. Periglacial features are common, creating what has been described as a "polar desert" (Bone, 1992: 20). In the Low Arctic Zone, shrubs, sedges, birches and willows pro-

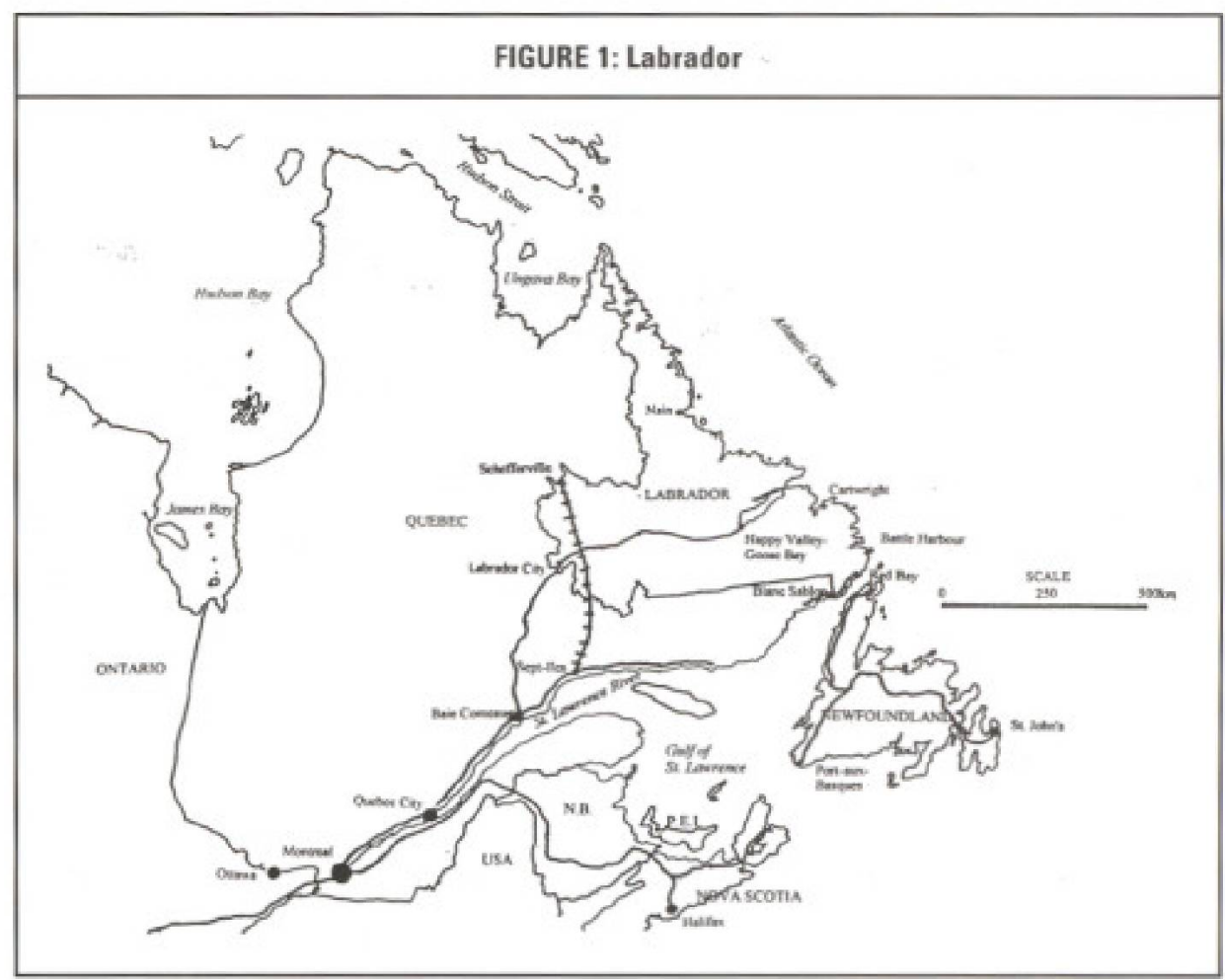

vide an almost complete cover to the landscape (Bone, 1992). These zones also support a diversity of edible berries including bakeapples, cranberries, gooseberries. raspberries, and currants that are important ingredients in local foods (Grenfell. 1895).

The presence of a treeline represents the dividing zone between the Arctic and Subarctic biome regions. As one goes northward, trees become more dwarfed with scrubs beyond the $59^{\text {th }}$ parallel (Grenfell, 1895). In the south, the boreal forest predominates supporting spruce, larch, pine, and fir, as well as birch and poplar in the extreme south (Bone, 1992). The northeasternmost Jack Pine stand in Canada is also found in southwestern Labrador and has recently been designated as an ecological reserve (WWF, 1998).

Arctic and subarctic vegetation is the basis for a food chain that supports large populations of fur-bearing animals including the largest caribou herd in the world, polar and black bear populations, moose, fox, otter, beaver, mink, marten, and lynx. These species attract nature tourists, adventurers, and sportsmen interested in nonconsumptive and consumptive tourism activities (Government of Newfoundland and Labrador, 1999; Grenfell, 1895).
Hydrologically, Labrador is part of the Atlantic and Hudson Bay drainage basins. Rivers running to the east, such as the Fraser River, drain into the Labrador Sea while those running west into Quebec, such as the Koroc River, drain into Hudson Bay. These basins support large numbers of trout and salmon and are the basis for an important outfitting and white water canoeing industry in the province. The Labrador Sea also supports an abundance of marine life including cod, capelin, herring, and flounder as well as rich seabird and waterfowl populations. Whales, seals, and per Busch, 1985; Grenfell, 1895). The largest Razorbill colony in North America is located off Cartwright at the Gannet Islands Ecological Reserve. The marine life has been important for marketing cruise ship tours, such as "iceberg alley", along the coast (Government of Newfoundland and Labrador, 1999).

In general, the abundant natural resources in the Arctic have served as the basis not only for resource exploitation and settlement, but also for the development of a tourism industry (Johnston, 1995). In Labrador, the wealth of natural resources is providing a diversity of attractions for vition identifies the tourist attractions linked to the rich cultural history of the region. shellfish also abound (Bone, 1992; Coositors in search of adventure. The next sec- 


\section{CULTURAL-EARLY SETTLERS TO LABRADOR}

The earliest settlers to Labrador arrived with the retreat of the glaciers approximately 10,000 year's ago. Small bands of hunter-gatherers settled in a series of campsites along the coast of southern Labrador. About 7,500 years ago these peoples developed a distinct way of life that came to be recognized as the Maritime Archaic Tradition (Tuck, 1976).

The Maritime Archaic Tradition was so named because it falls within the Archaic, or hunting and gathering stage of cultural development and because large parts of the people's lives seem to have been oriented to the sea and its products. (Tuck, 1976: 16)

Coastal camps were composed of several families who were mainly dependent upon land mammals and coastal resources. Using spears, harpoons, and stone knives, they hunted caribou, bears, beavers, whales, seals, walrus, and birds. They also fished for salmons and collected eggs and berries (Whalen, 1990; Tuck, 1976). Northward expansion of the Maritime Archaic people occurred more than 6,000 years ago. Hamilton Inlet and Saglek Bay contain evidence of Maritime Archaic settlements. The Maritime Archaic people disappeared from the coast an estimated 3,500 years ago (Tuck, 1976; Fitzhugh, 1972). In 1973, the oldest Maritime Archaic ceremonial burial site of a young child was discovered at L'Anse Amour on Labrador's south coast. Approximately 7,500 years old, the site was designated a National Historic Site in 1989 (Whalen, 1990).

The earliest Eskimo peoples, "Paleo-Eskimos," arrived in northern Labrador around 4,000 years ago from the Arctic islands to the north (Tuck, 1976). The Paleo-Eskimos occupied the coastal lowlands and flourished through a sea-based hunting economy that was centered on harvesting land and sea mammals, birds, and fish (Bone, 1992; Tuck, 1976). Evidence of their settlements has been found at Saglek Bay, Okak, Thalia Point, Napatok, Hopedale, and Hamilton Inlet (Tuck, 1976). The Paleo-Eskimo culture has been categorized as part of the Arctic Small Tool Tradition that "was based on the use of flint to shape bone and ivory into harpoons and other tools" (Bone, 1992: 39). The Paleo-Eskimos migrated as far south as Hamilton Inlet and disappeared at approximately the same time as the Maritime Archaic people 3,500 years ago (Tuck, 1976).

From 2,700 to 1,200 years ago another wave of Paleo-Eskimos, the Dorset Eskimos, settled in Labrador constructing semipermanent dwellings of turf and snow that were heated with oil lamps (Bone, 1992; Tuck, 1976). Their earliest settlements were located on the central Labrador coast with later settlements along all of coastal Labrador (Fitzhugh, 1972). The Dorsets developed a hunter-gatherer economy in the Arctic Small Tool Tradition with seals and caribou being an important part of their diet. Burial sites, as well as charms and amulets of seals and bears, also reveal the development of an elaborate set of religious beliefs for coping with the environment. By 1,000 years ago the Dorset people had departed from Labrador (Tuck, 1976).

The most recent arrival of Paleo-Eskimo people occurred approximately 500 years ago when the Inuit people or "true men" migrated across the Canadian Aretic in skin boats and dog sleds to Labrador (Bone, 1992; Tuck, 1976). Their transportation system was important for hunting seals, walrus, caribou, and bowhead whales. Ruins of their settlements have been found at Hopedale, Hamilton Inlet, and Saglek Bay where sod huts, stone graves, dumps, and artifacts have been discovered (Niellon and coll., 1984; Tuck, 1976; Fitzhugh, 1972). The dwellings of the Inuit reveal an evolution from small, oval structures. at Hopedale to rectangular, multi-family structures at Saglek Bay (Schledermann, 1980). The communal structures housed small, extended family units and were important socially for sharing food and economizing on materials and fuel (Bone, 1992; Tuck, 1976). Evidence suggests that hunting practices changed over time with whaling replaced by the harvesting of seals, fish, caribou, bears, and birds (Tuck, 1976). Artifacts also reveal an increasing European presence. The establishment of Moravian mission stations in Hebron and Nain, in the late 18 th century led to the eventual abandonment of traditional Inuit settlement sites and resettlement to these stations.
Two First Nation Peoples from the Algonkian Federation, the Naskapi and Montagnais, also settled in Labrador approximately 1,000 years prior to European contact. Up until the early $20^{\text {th }}$ century, the Naskapi and Montagnais resided in the interior barrens where they relied mainly on the caribou and salmon in their annual upstream migrations (Mak, 1984). Small groups of two to four families engaged in these hunts with large gatherings taking place around lakes in the spring and fall (Niellon and coll., 1984). Settlements were along rivers and lakes which formed the main communication routes (Mak, 1984). In the early 1900s the decimation of the caribou herd resulted in settlement at Davis Inlet. However, Fitzhugh's (1972) research at Hamilton Inlet also reveals evidence that a group of Naskapi did adapt to coastal living from 600 to 1300 A.D. where they established small campsites with tents and hearths that were important for hunting sea mammals, birds, fish, and land mammals.

Museums in Nain, Hopedale, and North West River document the history of these early Labrador settlers and provide visitors with the opportunity to understand how these peoples adapted to their hostile Labrador environment.

\section{EUROPEAN ARRIVALS}

The Vikings were the first European arrivals to the coast of Labrador during the 10th century where they traded with the Dorset or Thule people (Bone, 1992), Leif Eiriksson, son of Eric the Red, is one of the first Europeans who organized an expedition from Greenland and discovered a forested coastline with white sand beaches that he called Markland (Wheeler, 1998). Markland is now widely accepted to be present-day Labrador (Whalen, 1990). The discovery of the Viking settlement at L'Anse aux Meadows on the northern peninsula of Newfoundland in 1961 by Helge Instad indicates a Viking presence in the southern regions of Labrador some 500 years before the voyage of Columbus (Wheeler, 1998).

Not until the $16^{\text {th }}$ century is there further evidence of a European presence in Labrador. English explorers included John Cabot between 1497 and 1509; Portuguese and Spanish explorers made similar visits between 1500 and 1525; French explorer Jacques Cartier visited southern Labrador 
between 1534 and 1542 ; and Basque explorers came between the $1540^{\circ}$ s and 1580 's (Whalen, 1990). Initially, the European presence was seasonal from June to late autumn and was focused on the harvesting of the marine resources, specifically cod and whales (Proulx, 1993).

The Basques established an extensive whaling industry along the southern Labrador coast as early as 1543 (Barkham, 1982). In 16 th century Europe, whale oil was a prime source of light, a lubricant, a drug additive, and an ingredient for a variety of products such as soap (Grenier, 1985). By the 1570 's, 20 ships with a total of 1,500 to 2,000 men were hunting bowhead and right whales in the Strait of Belle Isle from the local ports of Blane Sablon, East St. Modeste, West St. Modeste, Red Bay, St. Peter's Bay, Chateau Bay, Carrol Cove, Pleasure Harbour, and Cape Charles (Barkham, 1982; Barkham, 1981). Red Bay, due to its sheltered harbor, boasted a population of 900 Basques during the summer season at the height of the fishery, in the second half of the 16th century (Tuck, 1985; Barkham, 1981). In 1977, the discovery of the San Juan, a Basque galleon which sank in 1565 at Red Bay, helped this small community to earn a National Historic Site designation (Barkham and Grenier, 1979). The Red Bay Interpretive Center, the Red Bay Heritage Museum, and guided trips to Saddle Island are a number of the highlights that have been organized for visitors wanting to learn about the Basque presence at what is believed to be the whaling capital of the world in the 16th century.

From 1660 to 1760 the cod fishery in southern Labrador developed slowly under the control of the French. Numerous raids by the Inuit during the $17^{\text {th }}$ century limited the development of a large scale fishery. In 1675 it is reported that only two French ships were fishing out of Blanc Sablon (Whalen, 1990). However, after the war between England and France, the Treaty of Utrecht established the French presence in Labrador giving them fishing rights,

By the beginning of the $18^{\text {th }}$ century, the King of France, who was the sole owner of southern Labrador at the time, conceded in perpetuity sections of the coast to merchants, civil and military officers. These concessions helped to establish permanent settlements in the region. In present-day Labrador these areas include Rivière-des-Français (Pinware River) (1716), Isle St. Modet (1735), Forteau and Anse-au-Loup (1748) (Whalen, 1990). Seal fishing became a profitable venture in the spring and fall with the fat being melted and barreled before being sent to Quebec City. By 1760 , four of the concessions, Grand Mecatina and Bradore Bay in present-day Quebec and St. Modet and Red Bay in present-day Labrador, employed 100 men, produced 1,000 barrels of oil, and 12,000 seal skins (Whalen, 1990).

The Labrador coast during the $17^{\text {th }}$ and $18^{\text {th }}$ centuries also became an important summer base for a French migratory fishery. Beginning in June, approximately 16 ships would arrive from France that were based in harbors along the south Labrador coast as far north as Cape Charles. These harbors served as stations for drying and curing cod which employed approximately 1,000 to 2,000 men with the production of dried cod averaging 41,236 quintals a year (Whalen, 1990).

By 1763 , the Treaty of Paris ceded Labrador to the British resulting in the reorganization of the fish trade in the region. From the 18th century to the late $20^{\text {th }}$ century mercantile premises were established at Battle Harbour and became a major base for the region's cod, seal, salmon, and herring fisheries for more than 200 years. The mercantile premises or "the room" were owned by a series of companies (see Table I).

By 1850 , Battle Harbour was widely regarded as the capital of the Labrador Coast and became the site of the first hospital for Wilfred Grenfell's infamous medical mission in 1892, the center of operations for the Newfoundland Ranger Force and Royal Canadian Mounted Police, and the site of Robert E. Peary's press conference on his accounts of reaching the North Pole in 1909 (Yates, 1997).

In 1992 with the closure of the fishery, the Earle family donated the premises to the Battle Harbour Historic Trust. The Trust was incorporated in 1990 to restore Battle Harbour, develop and promote the important historic and cultural resources of the community, and to diversify the local economy. In 1995, the Historic Sites and Monuments Board of Canada designated Battle Harbour as a national commemorative site of the Labrador fishery and in 1997 Battle Harbour was designated a National Historic District (Yates, 1997). The restored community offers an interpretive center, accommodations, and package trips for visitors wanting to experience Labrador's historic inshore fishery.

In the $18^{\text {th }}$ century, at the same time as the development of the Labrador's fishery, a Protestant community, the "United Brethren," or Moravians, initiated missionary endeavors in northern Labrador receiving a grant of 100,000 acres for a settlement in Nain (Rowe, 1980). Once established, they then expanded their missions to seven other sites along the coast (Government of Newfoundland and Labrador, 1999). These missions were centers where the Moravians worked with the Eskimos in the areas of religion, education, culture, and economy. Native language and culture, basic medical training, trading and cottage craft development, surveying and cartographical work, and natural history research were a number of subject areas where the Eskimos received training (Rowe, 1980). The missions at Hopedale and Nain, founded in 1782 and 1829 respectively, have been designated National Historic Sites (Government of Newfoundland and Labrador, 1999).

\begin{tabular}{|ll|}
\hline \multicolumn{2}{|c|}{ TABLE 1 } \\
\hline Owners of Battle Harbour premises & Dates \\
\hline John Slade and Company of Poole, England & $1750-1871$ \\
\hline Baine, Johnston and Company Limited & $1871-1955$ \\
\hline The Earle Freighting Service, Limited & $1955-1991$ \\
\hline Battle Harbour Historic Trust & 1992 -present \\
\hline
\end{tabular}

Source : Yates 1997 
This brief inventory provides evidence that there are numerous natural and cultural resources in Labrador that have been and are in the process of being developed for visitors. Protected areas, museums, interpretation centers, and historic districts have become focal points for tourists and are strengthening Labrador as a tourist destination. The next section discusses the accessibility of these sites and documents the traditional transit routes and circulation corridors that have brought tourists to this remote region of eastern Canada. Government efforts to increase the accessibility of the region are also discussed.

\section{TRANSIT ROUTES TO LABRADOR}

Transit routes are a vital component in the development of a destination and serve as the link between the destination region and the generating region (Lundgren, 1995). The growth of formal transit routes to Labrador began in the late 19th and early $20^{\text {th }}$ centuries using a network of land surface and water-based transportation systems (see Figure 2). In 1905, the Newfoundland Guidebook (Prowse, 1905: 92) reported that, "Labrador can be reached at present only via Newfoundland."

Visitors could take one of two government steamers from Port-aux-Basques on the west coast of Newfoundland or St. John's on the east coast, both of which met at Battle Harbour, Labrador.

The east coast boat starts from St. John's every formight and after calling at numerous places on the east side of Newfoundland, she meets the western boat at Battle Harbour and then goes all down the Labrador on the Atlanic side as far as Nain. She visits up both Hamilton Inlet and Sandwich Bay. The point at which she turns to the southward is about two-thirds of the way to the Hudson Bay Straits (Prowse, 1905: 92).

The steaners servicing Labrador were jointly owned by the Reid Newfoundland Company and Messrs. Bowring Brothers Ltd. of St. John's (Prowse, 1905). In 1898, the steamer service was linked to the "Newfie Bullet" which offered train service across Newfoundland from Port-auxBasques to St. John's (Baccalieu Consult-

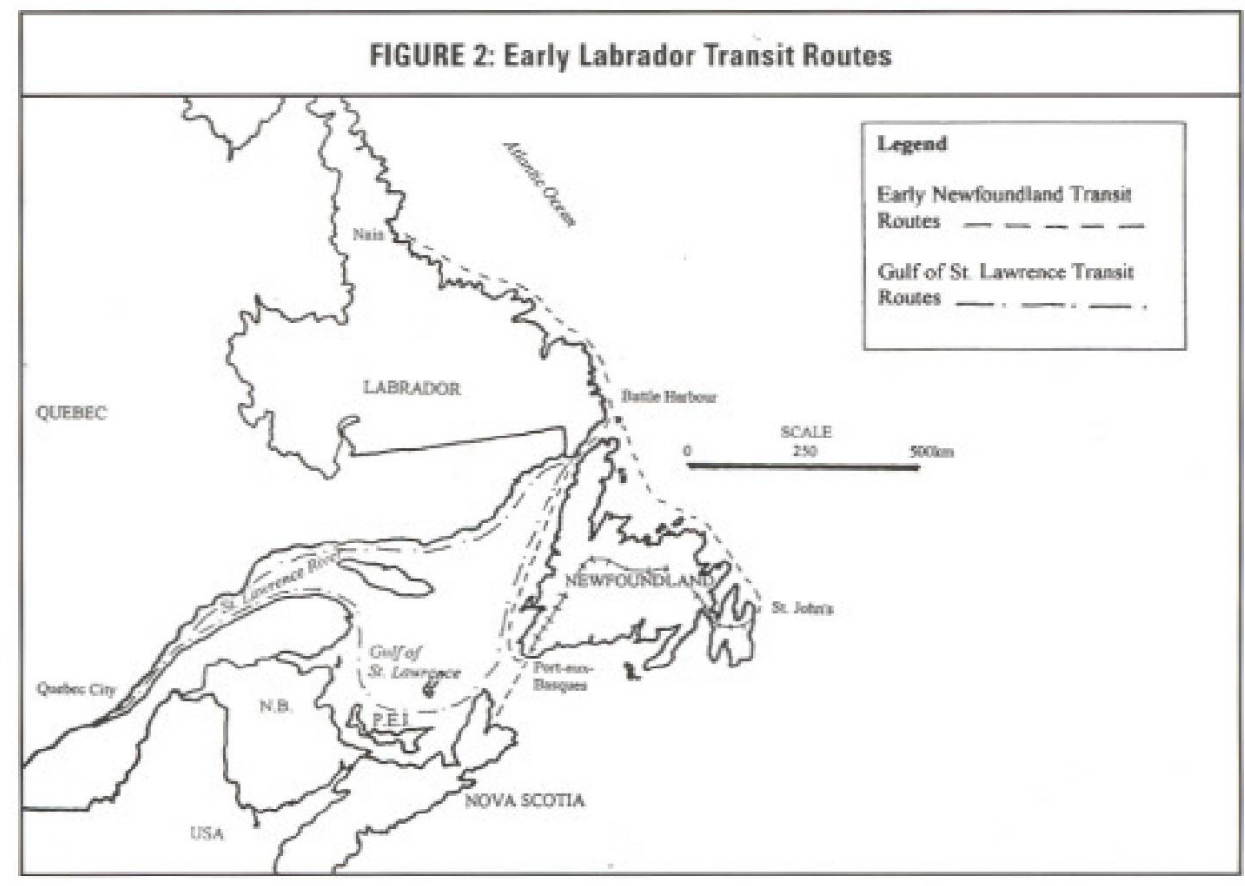

ing, 1999). At the beginning of the 20th century, it was therefore conceivable that visitors arriving at Port-aux-Basques or St. John's could take a circular touring circuit where they could combine the steamer service to Labrador with the train service across Newfoundland. In Labrador, visitors who were interested in touring Labrador's major rivers also had an option of transferring to the eastern mail steamer at Rigoletie or Indian Harbour and traveling to the Hudson Bay Post at North West River and the mill at the mouth of the Grand River (Prowse, 1905).

Not until the 20 's were there any alternative transit options for visitors traveling to Labrador. In 1920, the Clarke brothers founded Clarke Steamship Lines to serve ports of call in the St. Lawrence from Quebec City and Montreal. In an entry from the Clarke daybook (1978) it was reported:

The scenic splendors of the Gulf of the St. Lawrence which had first attracted the yachting Clarke brothers prompted the new line to develop pleasure cruises from Montreal to many picturesque ports in the Gulf. These cruises, operated by the S.S. New Northland and later by the S.S. North Star, brought thousands of tourists to this region for the first time. Labrador, the unknown country, became more than just a synonym for polar regions. The new cruises did much to make the people aware of the work of the Grenfell Medical Missions in the North Country and aided that enterprise in many ways, focusing attention on a region which proved to be so rich in natural resources which are now being developed.

In 1926 , a touring circuit was initiated which lasted until the end of the Second World War.

[... ] every other Monday during July and August the North Star left Montreal, destined for Quebec City, Gaspe, Charlottetown, Pictou, Corner Brook, St. Anthony, Forteau,

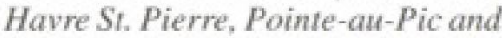
Quebec City[...].The New Northland also stopped at Harrington (Franck, $1980 ; 43)$.

In the journal of Placide Vigneau (1857 to 1926), his July 22,1922 entry reports that "a lot of tourists and government representatives have gone down on an excursion on the coast on board the North Shore" (Vigneau, 1969; 282). The Hudson Bay Company supply ship, the S.S. Nascopie which serviced the eastern Arctic also is reported to have provided tourists with a travel option through the region (Lundgren, 1995).

Steamship lines continue to be an important means of transportation for visitors 
to Labrador at the end of the $20^{\text {th }}$ century and are the preferred way of getting to the isolated outposts along the Labrador coast (Porter, 1988). The Northern Ranger calls at 48 communities making a round trip from St. Anthony, Newfoundland to Nain, Labrador, traveling more than 1,000 nautical miles in two weeks (Marine Atlantic, 1994). Another passenger and car ferry, Sir Robert Bond offers service from Lewisporte, Newfoundland to Happy Valley-Goose Bay, from mid-June to midSeptember on a 33-hour one way trip (Government of Newfoundland and Labrador, 1999). Rail, road, and air service development over the last 60 years are also helping to improve the accessibility of the region and providing transport options for visitors.

In 1954 direct rail service arrived to western Labrador with the development of the Quebec North Shore and Labrador Railway, a 566-kilometer rail line from SeptÎles to Schefferville, Quebec with stops in Labrador City/Wabush (Warkentin, 1997; Lundgren, 1995). The purpose of this line was primarily for transporting iron-ore deposits from Schefferville, Labrador City, and Wabush but passenger services were and still are available for visitors.

At the end of the $20^{\text {th }}$ century the road system in Labrador is still limited. In the 1970 's the Freedom Road was completed in central Labrador connecting Churchill Falls to Goose Bay. In 1992, this road, now called the Trans-Labrador Highway was extended and linked to the North American road system connecting Happy ValleyGoose Bay with Churchill Falls, Labrador City/Wabush, and Baie Comeau, Quebec (Warkentin, 1997). An 84-kilometer road from Blanc Sablon, Quebec to Red Bay, Labrador in the south was paved over the last two decades and is accessible by steamer service from St. Barbe, Newfoundland.

In the spring of 1999, the Government of Newfoundland and Labrador officially announced the extension of the road from Red Bay to Cartwright as part of a new Labrador Transportation Initiative. This CDN $\$ 130$ million project will begin in the summer of 1999 and is expected to take at least four years (Roberts, 1999). The road will link the communities of Labrador South to the Straits and the island of Newfoundland. Premier Tobin, "described the highway as a symbol of freedom and mobility for the people of Labrador adding that it will open the 'Big Land' to the world" (Roberts, 1999: 3). The government also announced that it will upgrade the road from Churchill Falls to Happy Valley. Goose Bay as part of the initiative (Roberts, 1999).

Air services to northern Canada have also been critical to the growth of tourism in the region. In the 1930 's passenger air service was available on demand to such destinations as Povungnituk, Labrador (Lundgren, 1995), although, due to the expense and danger involved, the demand for these early flights was minimal. The development of jet propulsion in the 70 's helped to decrease travel time to the North, increasing the accessibility of Labrador for tourists (Lundgren, 1995). Even so, air travel for tourists in the Canadian North continues to be affected by progressively increasing costs as one travels north due to distance (Johnston, 1995). In 1999, gateway airports in Labrador include Wabush and Goose Bay which have connections to St. John's, Halifax, and Montreal. These airports provide links to smaller airports in selected coastal communities (Government of Newfoundland and Labrador, 1999). During the summer months, Canadian Airlines even offers special "Fisherman's Flights" to the region (Marshall, Macklin, Monaghan Limited, 1989).

At the end of the 20th century, the transit routes for visitors to Labrador comprise a mix of air, land, and water-based services. The traditional ferry services are still in operation and remain an important means of transport for visitors who wish to experience the remote coast of Labrador. Over the last century, the accessibility of Labrador has increased with the development of rail, car, and air services. The recent approval of the road extension to Cartwright in Labrador South will also help

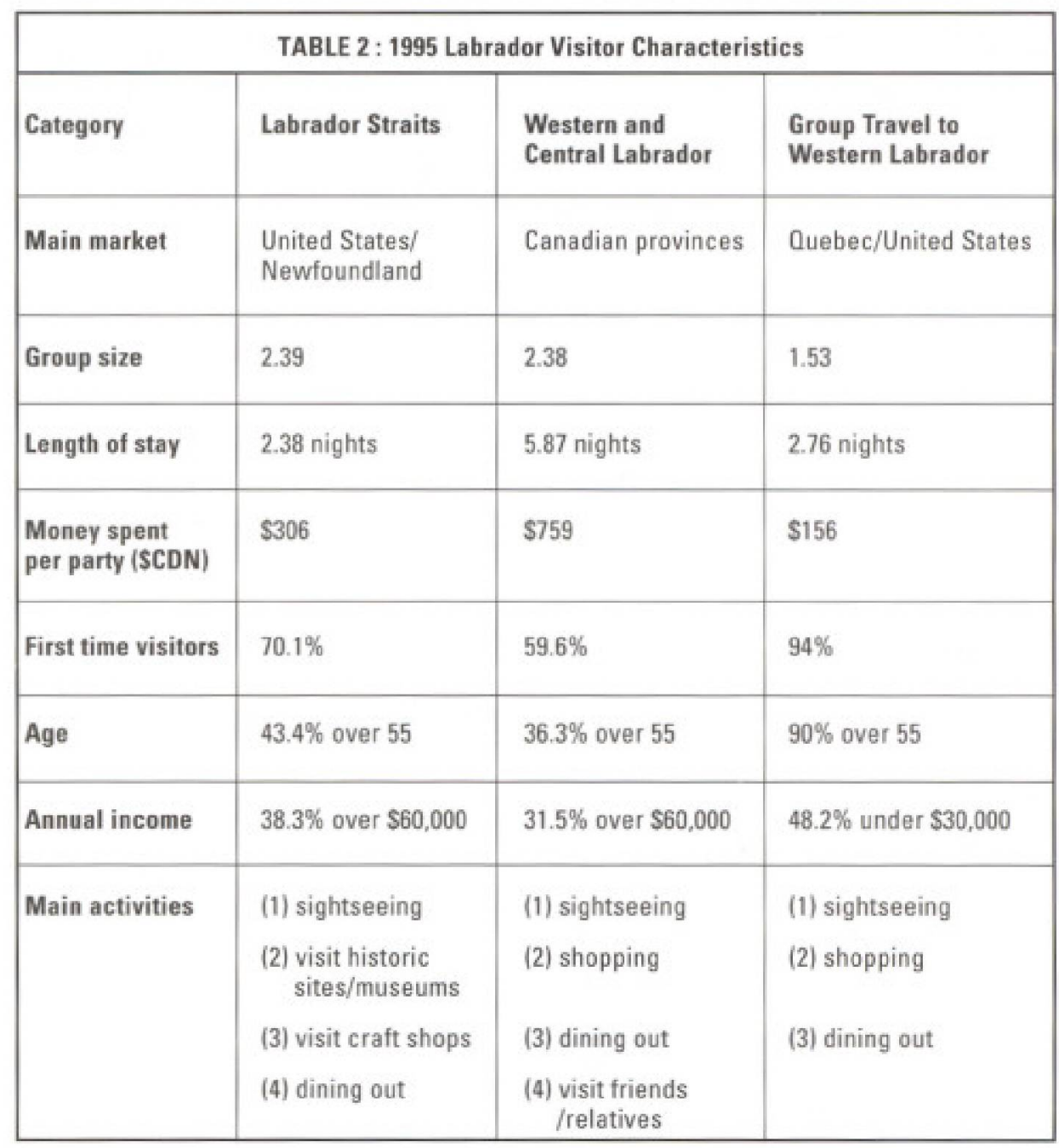

Source : Gowernment of Newfoundland and Labrador 1995 


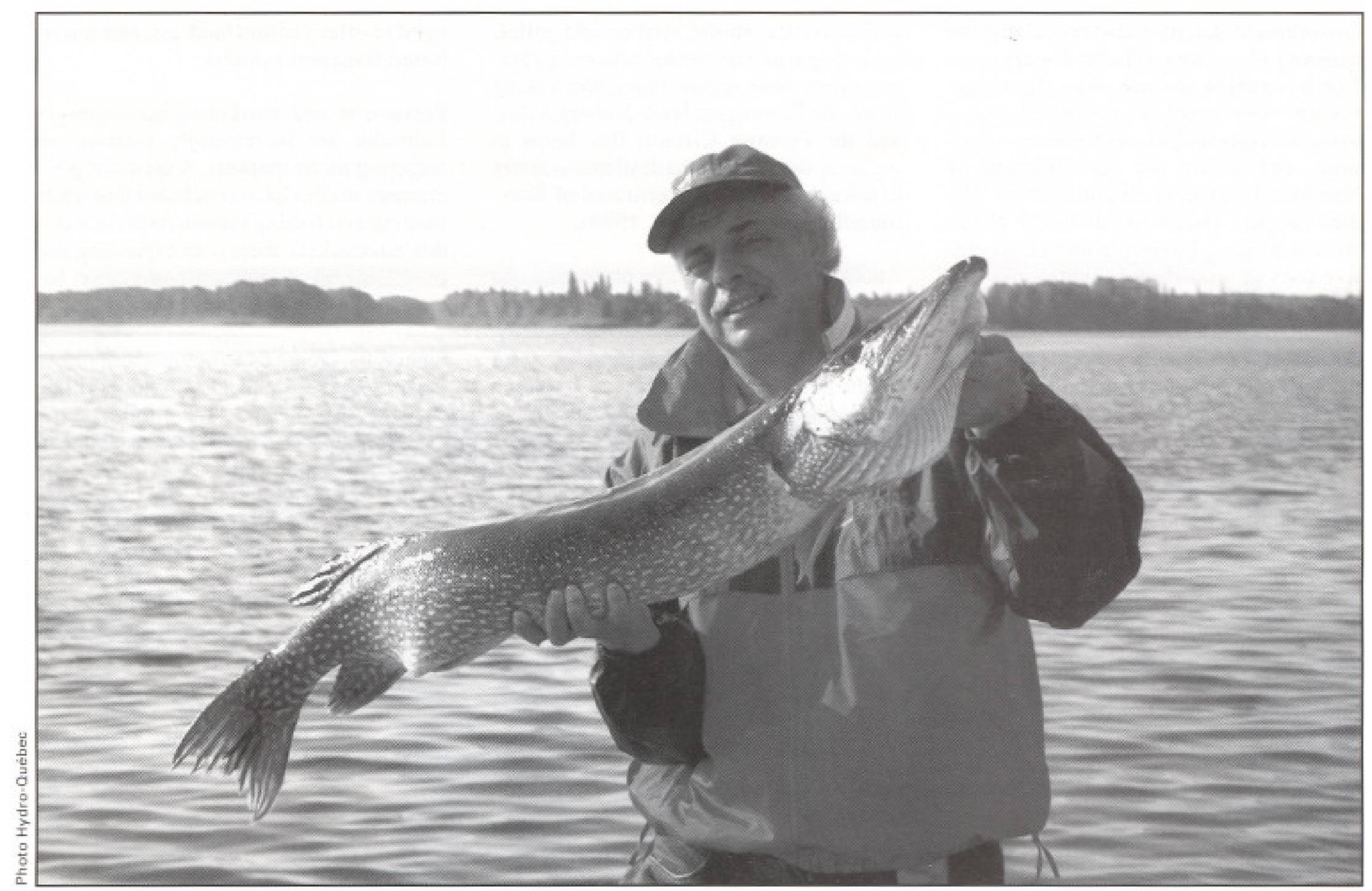

to extend the trip of Labrador visitors who are traveling north to reach "the end of the road." Even so, Labrador's location still makes it a long-haul destination for most visitors. The distance, time, and cost involved in getting to Labrador are the biggest constraints to growth and development (Economic Planning Group of Canada, 1996).

\section{THE GENERATING \\ REGIONS-ANALYZING TOURIST DEMAND}

The generating regions (where visitors come from) of visitors to Labrador can be evaluated by analyzing market demand. Tourist demand is traditionally based on a review of market studies and the process of planning to meet market needs (Gunn, 1994). This section therefore has two objectives: analyze visitor profiles to understand the sociodemographic characteristics and activities of Labrador tourists; and document government efforts to meet market needs through promotion and marketing strategies.
In 1905, Labrador was marketed as a destination for fishing in pristine, fastflowing rivers and sightseeing on cruise ships to spectacular northern landscapes (Prowse, 1905). The guidebook for Labrador reported : "Every harbour has a stream, and sea trout and salmon are all abundant [...]" (Prowse, 1905: 88).

For individuals interested in sightseeing, a trip to Labrador offered the opportunity to participate in a "small Arctic expedition" (Prowse, 1905: 114). Fishing and cruises remain important niche markets for the industry at the end of the $20^{\text {th }}$ century (The Economic Planning Group of Canada, 1996).

In 1995, the Government of Newfoundland and Labrador conducted, for the first time, an auto/train exit survey of visitors to Labrador from May to October in an effort to identify the travel characteristics of visitors (Government of Newfoundland and Labrador, 1995). Regional profiles were developed based on travel to the Labrador Straits, travel to western and central Labrador, and group travel to western Labrador. Table 2 presents a selected sociodemographic and activity profile of visitors.

In 1995, there were 11,105 visitors to Labrador, based on the survey. This figure is comparable to statistics for other arctic and subarctic regions of Canada. In 1993, Baffin Island received approximately 4,100 visitors while the subarctic northern frontier of the Northwest Territories received approximately 27,700 visitors (Johnston, 1995). Among the visitors to Labrador, approximately 8,200 or $75 \%$ spent their time in the Labrador Straits (Government of Newfoundland and Labrador, 1995). The accessibility of the Straits by car reinforces the importance of road access and highways as tourist corridors in the North (Johnston, 1995). As a result of the proposed road development in southem Labrador, one local hotel owner in Mary's Harbour commented that he would be investing $\$ 650,000$ to renovate his hotel and expand from 8 rooms to 30 rooms due to the expected influx of visitors following the opening of the road (Roberts, 1999). 
Government statistics also reveal that the majority of visitors to Labrador are from North America and are older, first-time visitors who travel in groups and whose main interests include sightseeing, shopping, and dining out (Government of Newfoundland and Labrador, 1995). The data support visitor trends in the North show a growing interest in non-consumptive uses of wildlife for sightseeing and wildlife viewing (Milne and coll.,1995; Johnston, 1995). Based on these findings, the next section identifies recent provincial priorities for promotion and marketing to strengthen and expand the visitor market of Labrador.

In 1990, the Provincial Government of Newfoundland and Labrador, the Economic Recovery Commission, tourist associations, and other parties initiated a process to develop an adventure tourism strategy for future development, to capitalize on the $30 \%$ annual growth rates of the international adventure tourism market (Government of Newfoundland and Labrador, 1993; Kallen, 1990). Adventure tourism was defined as leisure travel that takes place in an a wilderness destination where visitors engage in consumptive (hunting, fishing) and non-consumptive (hiking, white water rafting) activities (Department of Tourism, Culture and Recreation, 1994). As Genge (1991, 35: 37) points out, policymakers view adventure tourism as a key economic development strategy for the region.

Outfitting (consumptive) and adventure (non-consumptive) tours offer Labradorians year round employment, the dignity of living without handouts, and the chance to be on the ground floor of a burgeoning new industry that respects the land and culture of its Native residents.

In 1993, people in the travel-tourism industry in Labrador launched a promotional campaign, Destination Labrador, "to convince travel wholesalers, tour companies, travel media, cruise lines, and a host of others to promote Labrador to adventure travelers." (Destination Labrador, 1993: 1) The theme, "Awaken your heart and soul" featured not only the land and seascapes of Labrador but also its unique history and culture.

In the last decade the Province has also launched an annual four-section travel guide for visitors: scenic tours; attractions and activities; shops, studios and galleries listings; and accommodations. Labrador offers four scenic tours: the Viking Trail, the Ptarmigan Trail, Iceberg Alley, and the Frontier Circuit; this helps to organize the region into destination zones to attract visitors (Government of Newfoundland and Labrador, 1999).

Another more recent major promotion and marketing campaign in the province capitalizing on the adventure tourism strategy, has been the Newfoundland and Labrador Product Market Match Study, a 17-volume report commissioned by the Department of Tourism, Culture and Recreation (The Economic Planning Group of Canada, 1996: 1), "to identify the niche markets and niche products which offer the best potential for the province, in the national and international markets." As a result of the study, the following markets were identified for analysis: cultural tourism, nature tourism, hiking, scuba diving, canoeing/ sea kayaking, fishing, and winter tourism. Six business reports were also completed as part of the study for soft adventure operators, cultural entertainment programs, Labrador coastal cruises, winter adventure programs, learning vacations, and package trips to assist entrepreneurs and tourist associations in their planning and development of tourism in the province. These promotion and marketing strategies initiated in the last decade have helped to increase the competitiveness of Labrador as an adventure tourism destination.

\section{CONCLUSION}

At the end of the $20^{\text {th }}$ century adventure tourism development in Labrador has become a priority for policymakers attempting to diversify the economy as a result of the closure of the ground fishery in the early 90 's. In the last decade, natural and cultural sites in the region have been preserved and are now being developed as focal points for destination zones, in the hope that tourism will bring economic benefits to the residents of Labrador.

Government funding for infrastructure development is increasing the accessibility of the region by car while traditional cruise ship lines continue to be a popular form of transport for visitors who want to experience life in the remote outport communities. Over the last century, the transportation network has continuously devel- oped to offer visitors land, air, and waterbased transport options.

Promotion and marketing strategies in Labrador are increasingly focused on targeting niche markets. A series of government studies have concluded that while hunting and fishing remain important traditional markets, there is an expanding and promising adventure tourism market focused on non-consumptive activities.

One of the greatest challenges for policymakers and residents of Labrador will be to properly manage and minimize the negative impacts of increased development on the natural and cultural resources of the region. The sustainability and future success of tourism in Labrador will depend upon the degree of local control and the ability of managers to preserve the wilderness experience of this vast northern land that has attracted visitors and explorers to its shores for centuries.

John Hull is the Sustainable Communities Direcior at the Quebec-Labrador Foundation in Montreal, Quebec.

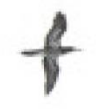

\section{BIBLIOGRAPHY}

Baccalieu Consulting (1999), The Newfie Bullet: a Narrow Gauge Railway, Yaffles and Yaffles, <http://www3,nf,sympatico.ca/mayad/ fish/nfbullet.htm>.

Barkham. Michael (1981), Aspects of Life aboard Spanish Basque Ships during the loth Century, with Special Reference to Terranova Whaling Voyages, Ottawa, Parks Canada.

Barkham, Selma (1982), "Documentary Evidence for 16th Century Basque Whaling Ships in the Strait of Belle Isle" in Early European Settlement and Exploitation in Atlantic Canada. Memorial University, St. John's, Newfoundland.

Barkham, Selma and Robert Grenier (1979), "Divers Find Sunken Basque Galleon in Labrador", Canadian Geographical Journal, 97, 3 (December 1978-January 1979), p. 61.

Boilieu, Lambert de (1969), Recollections of Labrador Life, Toronto, Ryerson Press.

Bone, Robert M. (1992), The Geography of the Canadian North: Issues and Challenges, Oxford, England, Oxford University Press.

Clarke Steamship Lines (1978), Clarke day book, Montreal.

Cooper Busch, Briton (1985), The War against the Seals: a History of the North American Seal Fishery, Montreal, McGill-Queen's Press. 
Destination Labrador (1993), "Destination Labrador Lances Promotional Campaign", Destination Labrador, February 1993, 1, 1.

Department of Tourism, Recreation and Culture (1994), An Adventure Tourism Strategy for Newfoundland and Labrador. Execulive Summary and List of Recommendations, St. John's, Newfoundland, Queen's printer.

Economic Planning Group of Canada (1996), Newfoundland and Labrador Product Market Match Stady, volume V; a strategy for nature tourism, St. John's, Newfoundland, Queen's Printer.

Ethos Consulting (1990), Adventure Travel in Eastern Canada: an Overview of Product and Market Potential. Volume 1. Prepared for Tourism Canada.

Fitzhugh, W. (1972), Envirommental Archeology and Culural Systems in Hamilton Inlet, Labrador: a Survey of the Central Labrador Coast from 3000 B.C. to she Present, Washington D.C., Smithsonian Institution Press.

Franck, A. (1980), Le fleave St-Laurent 19001960. L'llet-sur-Mer, Musée maritime du Québec.

Genge, N. (1991), "Outfitting and Adventure Tourism in Labrador: a Formula for Economic Renewal", Newforndland Lifestyle, 9, 4, p. 35-37.

Government of Newfoundland and Labrador (1995), Newfoundland and Labrador 1995: Labrador Auno/Train Exit Suney, Department of Tourism, Culture and Recreation, St. John's, Newfoundland.

Government of Newfoundland and Labrador (1999), Newfoundland and Labrador 1999: Travel Guide, Department of Tourism, Culture and Recreation, St. John's, Newfoundland.

Grenfell, Wilfred Thomason (1895), Vikings of Today, or Life and Medical Work Among the Fishermen of Labrador, London, Marshall.

Grenfell, W.T. (1909), Labrador, the Country and the People, New York, The Macmillan co.

Grenier, Robert (1985), "Excavating a 400Year-Old Basque Galleon", National Geo= graphic, July, pa 58-67.

Grey, W. (1858), Shetches of Newfoundland and Labrador, Ipswich, England, S.H. Cowell.

Gunn, Clare A. (1994), An Assessment of Tourism Potential in Newfoundland and Labrador with Notes and Recomnendations for a Planned Approach to Tourism Development, Conference Proceedings from Workshops Held in Newfoundland, September 9-19, Edited by H. MacLellan and D. Parsons, Hospitality Newfoundland and Labrador, St. John's, Newfoundland.

Hall. C.M. and M. Johnston (1995), "Introduc= tion: Pole to Pole, Tourism Issues, Impacts and the Search for a Management Regime in Polar
Regions", C.M. Hall and M. Johnston (Eds), Polar Tourism: Tourism in the Arctic and Antarctic Regions, Toronto, John Wiley and Sons, p. $1-26$.

Johnston, Margaret (1995), "Patterns and Issues in Arctic and Subarctic Tourism", C.M. Hall and M. Johnston (Eds), Polar Tourism: Tourism in the Arctic and Antarctic Regions, Toronto, John Wiley and Sons, p. 27-42.

Kallen, C. (1990), "Eco-Tourism; the Light at the end of the Terminal", E Magazine, JulyAugust.

Leiper, N. (1979), "The Framework of Tourism", Annals of Tourism Research, 6, 1, p. $390-407$.

Lundgren, Jan (1995), "The Tourism Space Penetration Processes in Northern Canada and Scandinavia: a Comparison" C.M. Hall and M. Johnston (Eds), Polar Tourism: Tourism in the Arctic and Antanctic Regions, Toronto, John Wiley and Sons, p. 43-61.

Lysaght, A. M. (1971), Joseph Banks in Newfoundland and Labrador, 1766: his Diary, Manuscripts and Collections, Berkeley, University of California Press.

Mak, A. (1984), "The Montagnais on the Lower North Shore: Past and Present" in The Lower North Shore, Quebec City, Minister of Cultural Affairs, p. 86-99.

Marine Atlantic (1994), Labrador Coastal Service, Port-aux-Basques, Newfoundland.

Marshall, Macklin, Monaghan Limited (1989), Central Labrador Regional Tourism Plan, Marshall Macklin Monaghan Limited, Toronto, Omnifacts Research Limited.

Milne, S., S. Ward, and G. Wenzel (1995), "Linking Tourism and Art in Canada's Eastern Aretic: the Case of Cape Dorset" Polar Record, 3,176, p. $25-36$.

Niellon, F., G. Samson, and C. Tremblay (1983), "Archaeology on the Lower North Shore: a Heritage to Discover and Preserve", The Lower North Shore, Quebec City, Minister of Cultural Affairs, p. 102-125.

Porter, H. (1988), "By Coastal Boat to Labrador", Newfoundland Lifestyle, 6, 5, p. 16-17.

Powell, Benjamin W. (1979), Labrador by Choice, Toronto, Testimony Press.

Proulx, Jean-Pierre (1993), Basque Whaling in Labrador in the 16th Century. Ottawa, Environment Canada, Parks Service.

Prowse, D. (1905), The Newfoundland Guide Book, Including Labrador and St. Pierre, London Bradbury, Agnew.

Roberts, T. (1999), "Works Starting on Red Bay Road to Cartwright this Summer: Premier Says it Will Open up the Big Land to the World", The Northerm Pen, St. Anthony, May 3. Section A, p. 3.

Rowe, F.W. (1980), A History of Newfoundland and Labrador, Toronto, MeGraw-Hill Ryerson.

Sayage, Candace (1994), Aurora, Vancouver, Greystone Books.

Schledermann, Peter (1980), Imuit Prehistory and Archaeology, Calgary, University of Calgary, Arctic Institute of North America.

Tuck, James A. (1976), Newfoundland and Labrador Prehistory, Ottawa, National Museum of Man/National Museums of Canadia.

Tuck, James A. (1985), “Unearthing Red Bay's Whaling History", National Geographic, July, p. $50-57$.

Vigneau, P. (1969), Journal de Placide Vigneau (1857-1926) (Rapport des Archives du Québec), Québec, n.p., Ministère des affaires culturelles.

Wallace, Dillon (1907), The Long Labrador Trail, New York, The Outing Publishing co.

Warkentin, J. (1997), Canada: A Regional Geography, Scarborough, Prentice Hall Canada.

Whalen, David J. (1990), Just One Interloper after Another: the Unabridged, Unofficial, Unauthorized History of the Labrador Straits, Forteau, Labrador, Labrador Straits Historical Development Association.

Wheeler, D.J. (1998), The Vikings in Newfoundland. Newfoundland and Labrador Tourism, http:/www.wordplay.com/

World Wildlife Fund Canada (1998), Endan= gered Spaces Progress Report on Canada's Wild Lands: Newfoundland and Labrador, Toronto, WWF Canada.

Yates, J. (1998), A Guide to Baile Harbour, Battle Harbour, Labrador, Battle Harbour Historic Trust. 